\title{
Occurrence and effects of a spring oxygen minimum layer in a stratified coastal water
}

\author{
Birger Kruse $^{1}$, Bjarke Rasmussen ${ }^{2, *}$ \\ ${ }^{1}$ Department of Marine Ecology and Microbiology, National Environmental Research Institute, PO Box 358 , \\ DK-4000 Roskilde, Denmark \\ ${ }^{2}$ Institute of Hydrodynamics and Hydraulic Engineering, Technical University of Denmark, Building 115, \\ DK-2800 Lyngby, Denmark
}

\begin{abstract}
The combined effect of pelagic respiration and stratification resulted in the development of an oxygen minimum layer in early April 1988 in the Kattegat, Denmark. Strong wind mixing in midMarch created a cold and homogeneous surface layer above a saltier and warmer bottom layer This was followed by a large outflow of low salinity Baltic Proper water, which covered the higher salinity Kattegat water and created a surface layer trapping the cold former surface water as an intermediate layer for several weeks. Wind forcing was insufficient to mix the intermediate layer with the water column above. In this cold layer, 1 or 2 subsurface chlorophyll a maxima were observed, and the composition of the plankton community changed during the spring period towards heterotrophy, culminating with a maximum of 2200 ind. $1^{-1}$ of rotifers in the pycnocline at the end of April. In the bottom part of the cold layer a distinct layer exhibiting an oxygen minimum developed. In early April the layer was observed $10 \mathrm{~km}$ off the coastline and covered approximately $500 \mathrm{~km}^{2}$ The upper $10 \mathrm{~m}$ of the water column was at the same time supersaturated, with a maximum of $152 \% \mathrm{O}_{2}\left(554 \mu \mathrm{M} \mathrm{O}_{2}\right)$, presumably due to spring bloom photosynthesis. The oxygen saturation in the bottom water was $70 \% \mathrm{O}_{2}$, whereas an oxygen minimum was recorded below the chlorophyll a peak between the surface and bottom layers. Here, the oxygen saturation was $32 \% \mathrm{O}_{2}\left(120 \mu \mathrm{M} \mathrm{O}_{2}\right)$ with a plankton respiration of $14 \mu \mathrm{M} \mathrm{O}_{2} \mathrm{~d}^{-1}$. yielding an oxygen turnover of $8 \mathrm{~d}$. Where the pycnocline intersected the bottom, maxima of phytoplankton biomass $\left(33 \mu \mathrm{g}\right.$ chlorophyll $\left.\mathrm{a}^{-1}\right)$, plankton respiration rates $\left(16 \mu \mathrm{M} \mathrm{O}_{2} \mathrm{~d}^{-1}\right)$ and bacterial net production rates $\left(3.6 \mu \mathrm{M} \mathrm{C} \mathrm{d}^{-1}\right)$ occurred. Including the sediment oxygen uptake, an oxygen turnover of approximately $3 \mathrm{~d}$ was estimated in this zone, and only $2 \%$ of full oxygen saturation $\left(6 \mu \mathrm{M} \mathrm{O}_{2}\right.$ concentration) was found. Microzooplankton and flagellates accounted for approximately $1 / 3$ of the total oxygen consumption. The vertical position of the pycnocline changed during April and May, which resulted in fish mortality when fish trapped in the bottom nets were exposed to the oxygen minimum layer. At the end of May, the oxygen minimum layer was no longer distinguishable from the Kattegat bottom water.
\end{abstract}

KEY WORDS: Oxygen minimum layer Plankton respiration - Coast - Stratification Pycnocline . Eutrophication · Fish kill

\section{INTRODUCTION}

For coastal waters and stratified areas, temporary oxygen depletion events with fish mortality and a reduction in the diversity of benthic fauna have been

\footnotetext{
-Addressee for correspondence; present address: Department of Marine Ecology and Microbiology, National Environmental Research Institute, PO Box 358, DK-4000 Roskilde, Denmark.E-mail: hmbr@dmu.dk
}

recorded throughout the past century (Rumohr 1986). However, widespread oxygen deficiency events have become an increasing problem in bottom waters along the European and North American coasts since 1980 (Rosenberg 1985, Boesch \& Rabalais 1991). Although the causes of these events are still under debate (Malone 1991, Stanley \& Nixon 1992), these phenomena are linked to anthropogenic nutrient enrichment in temperate stratified waters (Andersson \& Rydberg 1988). Eutrophication is believed to increase primary produc- 
tion and sedimentation of organic matter leading to higher decomposition rates in the bottom water and/or within the sediments (Rydberg et al. 1990). Higher degradation rates are stimulated by the seasonal increases in bottom water temperature, which in the stratified Kattegat reaches its maximum in late summer (Ertebjerg et al. 1981). The accelerated biological activity and scant replenishing of oxygen by mixing can then lead to exhaustion of the oxygen content near the bottom (Jorgensen 1980).

When examining oxygen depletion events, it has been difficult to distinguish anthropogenic biological effects from natural variations, especially with respect to the physical parameters. Malone (1991) has argued that the oxygen deficiency problems recorded from Chesapeake Bay in the 1980's were a result of extraordinarily high freshwater runoff causing strong stratification rather than direct biological effects from the nutrient load itself. In addition, seasonal variations and the relative importance of respiratory processes of different trophic levels and between pelagic and benthic components have been discussed. For instance, it has been debated how much of the overall respiration takes place in the plankton community compared with the sediment oxygen uptake caused by heterotrophic and chemical processes (Kanneworff \& Christensen 1986, Graf 1987). Based on research carried out in the past decade, it seems likely that the respiratory potential of pelagic organisms is substantial (Westerhagen 1986, Welsh \& Eller 1991, Kemp et al. 1992).

In the Kattegat and the Belt Sea, hypoxia and anoxia have been repeatedly observed since 1981 . These phenomena, which occur in the late summer season, have been assessed as being effects of marine eutrophication (Kronvang et al. 1993). However, in 1984 fishermen in a small area of the southern Kattegat for the first time found dead fish in their nets at approximately $15 \mathrm{~m}$ depth in early April. Similar incidents were observed in 1986 (Frederiksborg Amt 1990) and during the present study (observations in 1988). Anoxia phenomena, at this time of the year, were considered very unusual by the authorities. This was, therefore, seen as a new type of eutrophication effect.

Recently there has been a focus on biological processes at the pycnocline in the Kattegat. Several papers have described the occurrence of maximum phytoplankton concentrations. Bjørnsen \& Nielsen (1991) found up to
$72 \mu \mathrm{g} \mathrm{chl} \mathrm{a} \mathrm{l}^{-1}$ in a narrow subsurface stratum in the southern Kattegat with reduced microzooplankton abundance and bacterial production. These observations were seen during the summer during a relatively stable hydrographic period. The aim of the present investigation was to describe the occurrence of the oxygendepleted layer in view of species composition and pelagic respiration and of physical forcing in terms of stratification and wind mixing. The combined effect of these physical and biological processes led to the fish kill in early April 1988.

\section{METHODS}

Study area. The Kattegat (Fig. 1) is a layered system consisting of salt and dense water below a pycnocline, while outflowing, less saline water from the Baltic Proper creates a surface layer (Dietrich 1954, Pedersen \& Møller 1981). Measurements were conducted in the southern part of the Kattegat, which has a windswept shallow water coast and a bottom topography of gradually deepening plains with sandy and sandy/silty surface sediments. The water depth increases about $1 \mathrm{~m}$ $\mathrm{km}^{-1}$ northwards up to a deeper channel along the Swedish coast. A total of 18 stations were visited during the investigation to identify the area of oxygen depletion. Results from 7 stations (Stns 1 to 7 ) representing increasing depths are shown. Time series covering measurements from the spring period are pre-

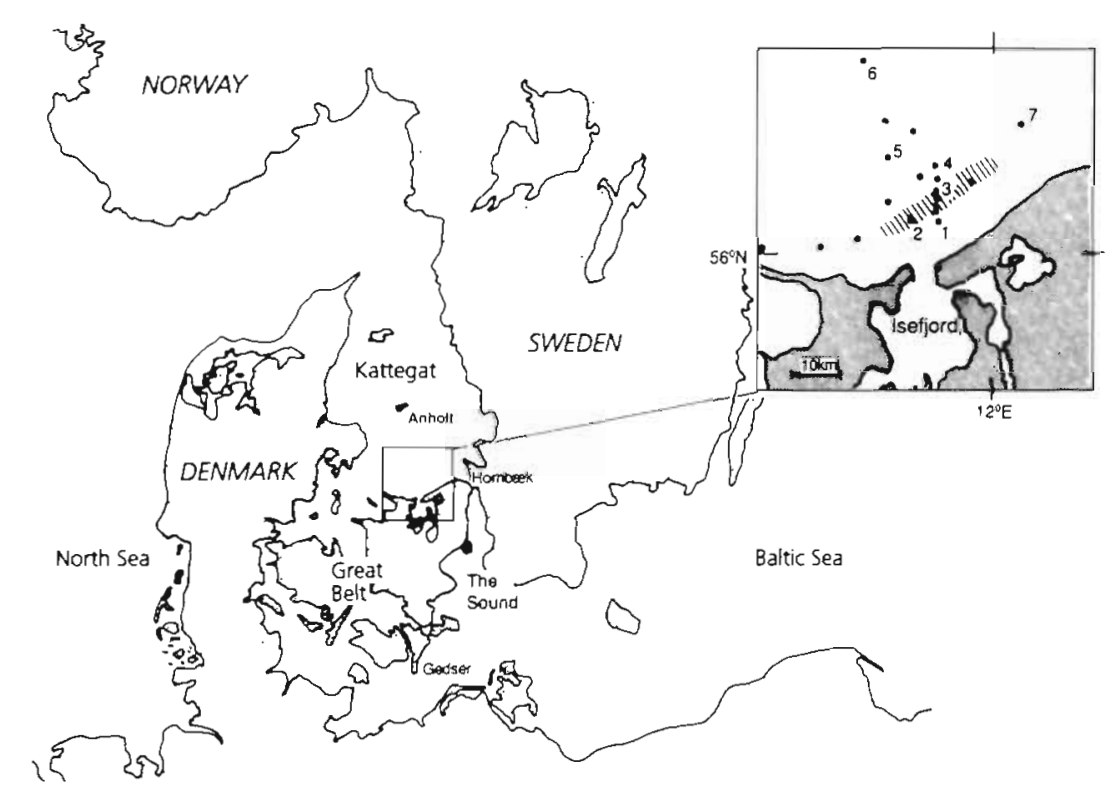

Fig. 1. Location of the area of investigation in the southern Kattegat. Samplung stations are indicated with black dots. Hatched field indicates the area where oxygen saturations from 2 to $30 \% \mathrm{O}_{2}$ were found in early April 
sented from $\operatorname{Stn} 3$ in the centre of the oxygen depletion area. Sampling near this station was carried out 1 to 2 times a day during the oxygen depletion in the first week of April 1988, followed by sampling approximately every 10 th day until the end of May.

Physical and chemical variables. Air temperature and wind velocity data from the southern Kattegat were obtained from the Danish Meteorological Institute. The air temperature is given as a mean of 4 stations surrounding the Kattegat. The wind velocity is shown as the integrated cubed wind velocity from Nakkehoved Lighthouse $8 \mathrm{~km}$ NE of Hornbæk (see Fig. 1) This can, roughly, be taken as being proportional to the theoretical change in the potential energy of the water column due to wind mixing (Simpson et al. 1990). Seawater level data were obtained from sea level gauges in Gedser and Hornbæk harbours to calculate the magnitude and direction of the flow through the Belt Sea (Jacobsen 1980). During the cruises, profiles of temperature and salinity were obtained using a Guildline CTD (conductivity/temperature/depth probe) (coefficient of variation, $C V, \pm 0.01 \% \mathrm{~S}$ and $0.005^{\circ} \mathrm{C}$ ) on board the RV 'Gunnar Thorson' during the intensive sampling period, and using a WTW-LF191 probe $(\mathrm{CV} \pm 0.1 \% \mathrm{~S}$ and $0.1^{\circ} \mathrm{C}$ ) on board small vessels until the end of May. Since the vertical salinity differences are much larger than the temperature differences, the effect of temperature on the stratification can be neglected. The vertical distribution of oxygen saturation was determined using an oxygen electrode (WTW-OXI-196 probe, CV $\pm 1 \%$ $\mathrm{O}_{2}$ saturation) calibrated in vapour-saturated air and verified by use of Winkler oxygen titrations of water samples ( $\mathrm{CV} 0.1 \mu \mathrm{M} \mathrm{O}_{2}$ ). The depth resolution of the probe measurements was approximately $0.2 \mathrm{~m}$ during calm weather and $0.5 \mathrm{~m}$ during normal conditions. Data were plotted every $1 \mathrm{~m}$ and curves fitted by eye. The oxygen saturations were recorded and plotted every 1 to $2 \mathrm{~m}$ in the surface water column but with finer resolution around the pycnocline and above the sediment surface. The oxygen measurements were conducted throughout the day during the intensive sampling period, and between 11:00 and 15:00 h during in the remaining period of April-May.

Biological measurements. In situ fluorescence profiles were obtained by a Q-instrument fluorometer (Hundahl \& Holck 1980) attached to a framed instrument composed also of the WTW-probes. The fluorescence was obtained by using Schott-glassfilters as follows: excitation BG18 (3 mm, blue glass) and emision RG 665 (6 mm, red glass). The fluorometer was connected to an X-Y plotter, and the profiles were digitized by eye. Light attenuation was measured by use of a Secchi-disk according to Nielsen \& Bresta (1984). From 2 selected depths, water samples were taken for chlorophyll a determinations to be used in calibrating the fluorescence values. After filtration of $4 \mathrm{l}$ of seawater $(0.8 \mu \mathrm{m}$ fibreglass filter) and extraction following Jespersen \& Christoffersen (1987), the chlorophyll a content of the water samples was obtained spectrophotometrically. One litre subsamples were taken $1 \mathrm{~m}$ above and within the pycnocline for phyto- and zooplankton enumeration using microscopy. Twenty $\mathrm{ml}$ subsamples were taken for measurement of bacterial biomass and production using a modified TTI-method (Tritiated Thymidine Incorporation) according to Hobbie et al. (1977) and Bjornsen (1986). Plankton respiration in the pycnocline was determined as dark uptake of oxygen in water samples incubated at in situ temperatures. The oxygen concentration was measured by precise Winkler procedure (Williams \& Jenkinson 1982, Kruse 1993) in $125 \mathrm{ml}$ calibrated bottles (5 replicates) before and after $24 \mathrm{~h}$ of incubation according to Kuparinen (1987). A 4-point test was made for the linearity of the respirational process.

\section{RESULTS}

\section{Meteorology}

Strong winds from the northwest dominated the wind climate in the southern Kattegat from the end of February until mid-March. The time-integrated wind velocity cubed (Fig. 2a) shows that, from mid-March until the second week of April, the cubed wind velocity was low. Apart from these events only short periods of high wind velocities were found; for example, on 7 April and 20 April. Until mid-March, the air temperature was low (Fig. 2b) during the strong wind. With the decline of the wind velocity, the air temperature rose to $4.5^{\circ} \mathrm{C}$ and increased from the onset of spring until mid-May.

\section{Hydrography}

The flow through the Belt Sea is shown in Fig. 2c. In connection with weak easterly winds in mid-March, an outflow from the Baltic Proper was abserved. This gave rise to an input of surface water with a salinity between 12 and $14 \%$ to the eastern and western parts of the southern Kattegat. The outflow lasted until the next event of strong westerly winds in the first week of April, which caused the flow to reverse and produced an inflow to the Baltic Proper until 12 April. During the rest of April until mid-May, there was mainly an outflow from the Baltic Proper.

Salinity and temperature data from 7 March and 6 April at Stn 7 are shown in Fig. 3. The upper part of the water column was well mixed to a depth of $10 \mathrm{~m}$ on 7 

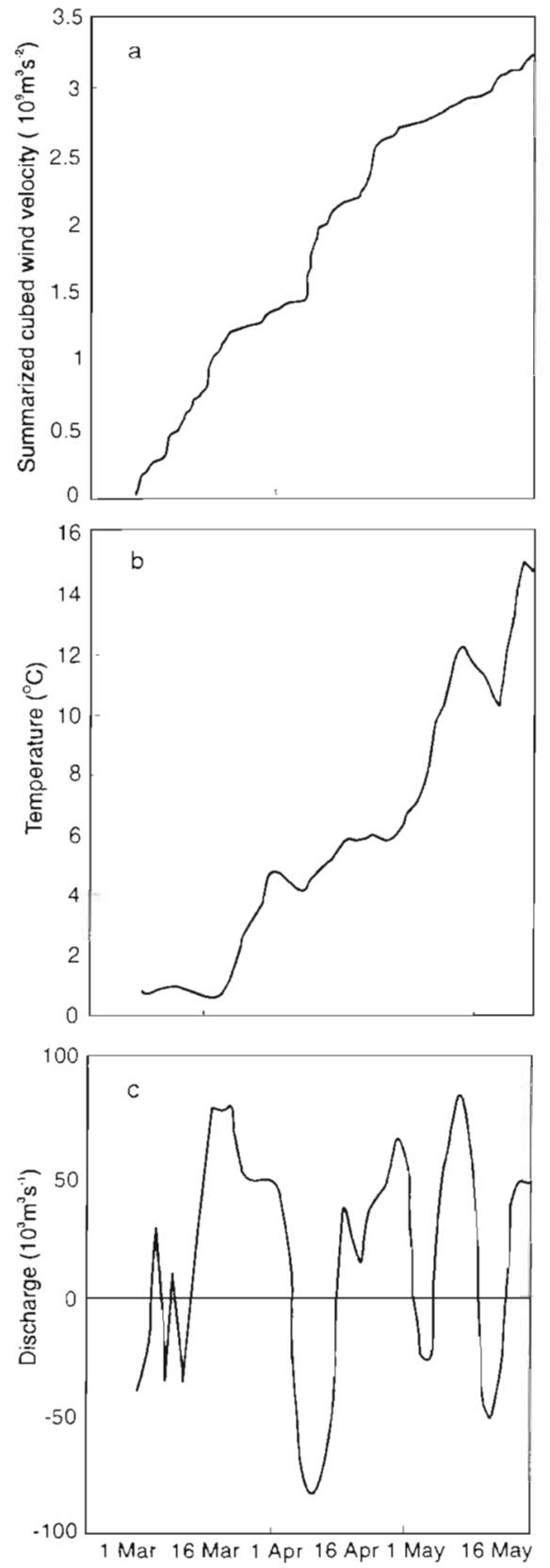

Fig. 2. Meteorological and hydrographic parameters in the southern Kattegat during the spring period. (a) Development in the time-integrated wind velocity cubed. (b) Rise in air temperature. (c) Calculated outflow from the Baltic Sea to the Kattegat

March with a salinity of $19.7 \%$ and a temperature of $2.3^{\circ} \mathrm{C}$. Between the surface and bottom waters, an intermediate layer was found at $16 \mathrm{~m}$ depth encompassing the largest salinity gradient (here referred to as the primary pycnocline). On 6 April, a surface layer salinity of $12 \%$ was found down to $2 \mathrm{~m}$ depth (Fig. 3a). The temperature was here $4.8^{\circ} \mathrm{C}$ (Fig. $3 \mathrm{~b}$ ). Just above
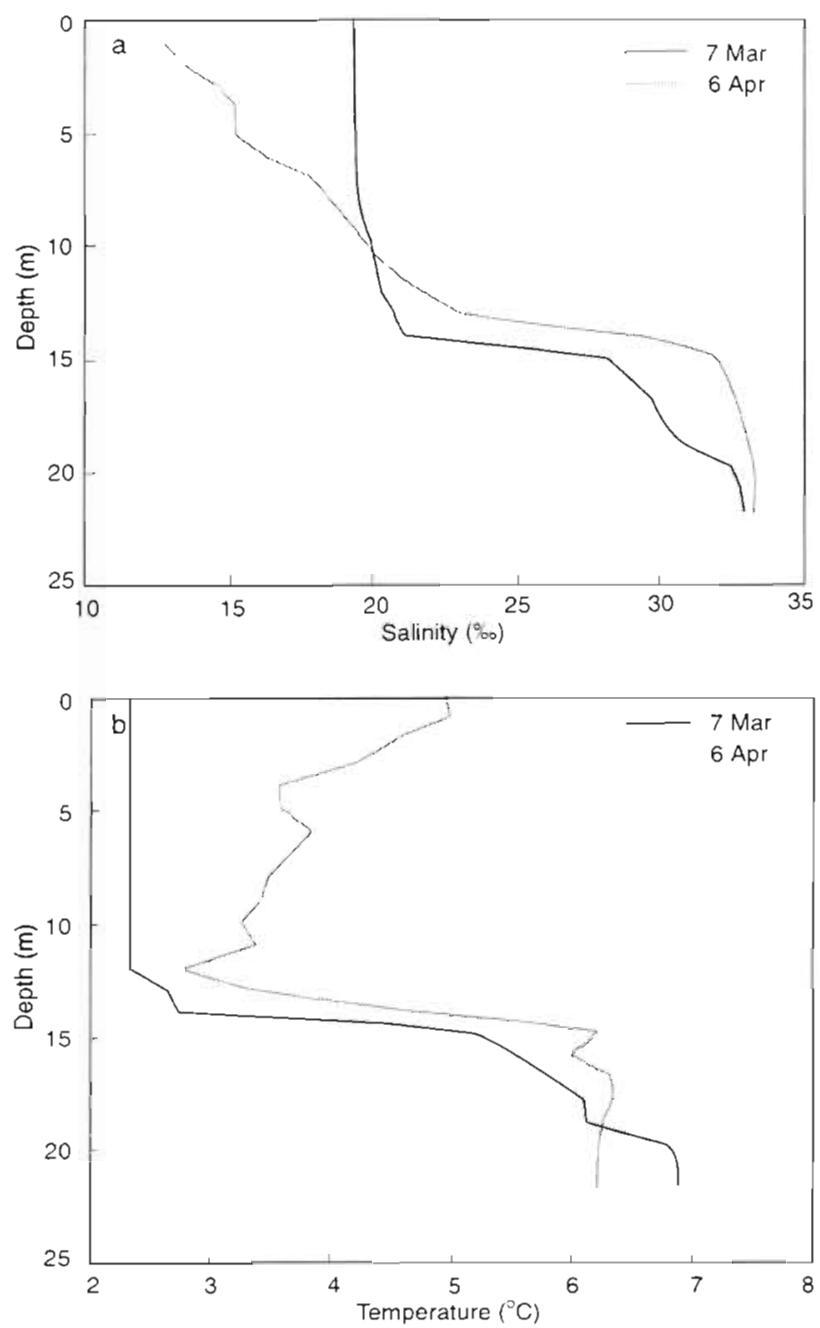

Fig. 3. (a) Salinity and (b) water temperature profiles at $\operatorname{Stn} 7$ on 7 March and 6 April. Homogenized and cold upper water layer has been replaced by less saline water masses from the Baltic Proper during this period. A subsurface cold water layer with $21.5 \% \mathrm{~S}$ and $2.7^{\circ} \mathrm{C}$ was thus created. It should be noted that the denser lower layer has been moved upwards during this period

the primary pycnocline at $13 \mathrm{~m}$ depth, the temperature had a minimum value of $2.7^{\circ} \mathrm{C}$ and a salinity of $22 \%$. From the coastline northwards along Stns 1 to 6 , the salinity in the upper part of the water column decreased slightly from $14 \%$ near the coast at Stn 1 to $12 \%$ off the coast at $\operatorname{Stn} 6$ at the beginning of April (Fig. $4 a$, b). Below the warm surface layer, a temperature minimum layer was found over the whole area, but with slight variations in magnitude. In addition, the depth of the temperature minimum layer changed with the position of the primary pycnocline. The temperature minimum could be identified above the primary pycnocline until mid-May (Fig. 5a, b). The temperature in the cold layer slowly increased from 2.7 to $5.4^{\circ} \mathrm{C}$. 



Fig. 4. Profiles of hydrographical and biological variables along Stns 1 to 6 at the beginning of April. (a) Salinity (Reference lines: 15, 20 and 25\% S). (b) Water temperature (Reference lines: 3 and $5^{\circ} \mathrm{C}$ ). (c) Oxygen saturation (Reference lines: 50 and 100\% $\mathrm{O}_{2}$ ). (d) Chlorophyll a. Data calculated from fluorescence profiles calibrated with measurements on water samples (Reference lines: 0 and $10 \mu \mathrm{g}$ chl a $\mathrm{l}^{-1}$ ). Very low oxygen values are seen at the bottom at Stns 2 and 3 . The oxygen minimum layer is found in the halocline just below the cold and chlorophyll a-rich water layer
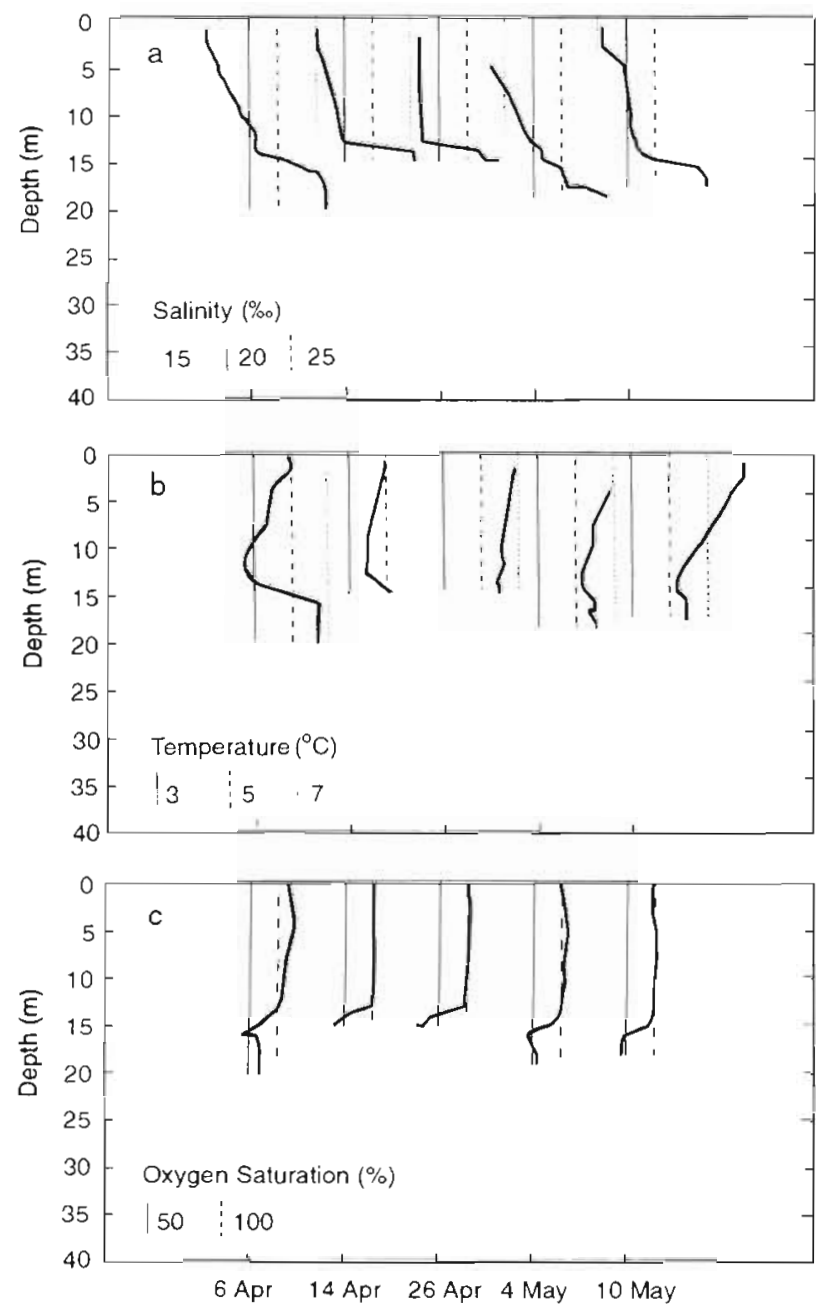

Fig. 5. Change in water column profiles during the sampling period at Stn 3 except on 4 May when the profile measurements were conducted at a deeper locality $2 \mathrm{~km}$ north of the station. The reference lines represent the same values as in

Fig. 4. (a) Salinity. (b) Temperature. (c) Oxygen saturation

\section{Chlorophyll a distribution and plankton species}

Secchi-depths of 3 to $4 \mathrm{~m}$ were recorded in the water column during the first week of April, corresponding to a relative irradiance of $1 \%$ at 7 to $10 \mathrm{~m}$ according to Nielsen \& Bresta (1984). The chlorophyll a concentration ranged between 6 and $33 \mu \mathrm{g} \mathrm{l}^{-1}$ chlorophyll $a$. The vertical distribution of fluorescence showed a subsurface maxima (Fig. 4d). In all fluorescence profiles, a maximum was always found at $c a-1 \mathrm{~m}$ above the primary pycnocline at depths of 12 to $15 \mathrm{~m}$ in connection with the temperature minimum layer, which was well below the depth of $1 \%$ irradiance. At the beginning of April, the highest fluorescence values were detected along the transect in the area where the primary pycnocline intersects the bottom, as shown in Fig. $4 \mathrm{a}$, d. 
Table 1. Dominant species of the phytoplankton and flagellates from samples taken in the pycnocline at Stn 3

\begin{tabular}{|lrcc|}
\hline Taxa $\left(10^{3}\right.$ cells $\left.\mathrm{I}^{-1}\right)$ & 14 Apr & $26 \mathrm{Apr}$ & 10 May \\
\hline Cryptophyceae spp. & 0.7 & 1.8 & 5.4 \\
Gyrodinium spp. & 1.9 & - & - \\
Protoperidinium spp. & 0.6 & 0.2 & 0.1 \\
Dinobryon balticum & 12.0 & 20.0 & 0.6 \\
Chaetoceros spp. & 131.7 & 113.0 & 0.9 \\
Coscinodiscus spp. & 0.2 & 0.04 & 0.2 \\
Rhizosolenia spp. & 0.8 & 3.8 & - \\
Skeletonema costatum & 460.0 & 1703.0 & 134.4 \\
Nitzschia spp. & 9.3 & 10.6 & 0.5 \\
Thalassionema nitzschia & 151.2 & 152.0 & 10.4 \\
Flagellates & & & \\
Choanoflagellates & 14.6 & 779.0 & 0.4 \\
Monads & 5.6 & 13.2 & 1.1 \\
\end{tabular}

Closer to the coast, in the absence of the high salinity bottom layer, maximum fluorescence values were found just above the sediment.

At the beginning of April, the plankton community in the water column was dominated by diatoms and some heterotrophic flagellates (Table 1), although some of the species did not look healthy in the primary pycnocline. This was the case with Chaetoceros spp., Rhizosolenia spp. and Coscinodiscus spp. Heterotrophic flagellates and monads were only present in the samples in moderate numbers, whereas microzooplankton such as tintinnids, naked oligotrichs and ciliates were found in numbers of 8500 ind. $1^{-1}$ (Table 2). By the end of April, the species composition had changed. Within the primary pycnocline, the number



Fig. 6. Depth distribution of oxygen saturation measurements (o) conducted at Stns 1 to 6 during the first week of April. Supersaturation is clearly demonstrated in the upper layer. The lowest oxygen saturations were recorded from depths around $15 \mathrm{~m}$ and especially from measurements $<1 \mathrm{~m}$ above the sediment surface $(\bullet$
Table 2. Microzooplankton abundance in samples taken from the pycnocline at $\operatorname{Stn} 3$

\begin{tabular}{lccc|}
\hline Taxa (ind. l $^{-1}$ ) & 14 Apr & 26 Apr & 10 May \\
\hline Tintinnid ciliates & 4900 & 500 & 360 \\
Other ciliates & 3400 & 850 & 270 \\
Nauplii spp. & 25 & - & - \\
Copepodite spp. & - & 5 & - \\
Rotatora spp. & 125 & 2200 & 15 \\
Bivalvia spp. & 10 & - & 10 \\
Nematoda spp. & 5 & 5 & - \\
Cladocera spp. & - & 5 & - \\
\end{tabular}

of heterotrophic Gyrodinium spp. and Protoperidinium spp. had decreased; however, the number of diatoms and, especially, the number of choanoflagellates and rotifers had increased to $22001^{-1}$ in the primary pycnocline. In May, the spring bloom was over as demonstrated by low values of all other plankton parameters even though Skeletonema spp. still dominated (Tables 1 \& 2).

\section{Oxygen distribution}

In the first week of April, oxygen supersaturation was observed in surface waters as well as in the upper part of the cold layer above the primary pycnocline (Fig. 4c). Values of 135 to $152 \% \mathrm{O}_{2}$ were found at a depth of $1 \mathrm{~m}$. At $10 \mathrm{~m}$ depth the range of oxygen saturation was 117 to $120 \% \mathrm{O}_{2}$ throughout the area investigated (Fig. 6). During the next 2 wk, the magnitude of supersaturation measured in the surface layer had decreased to $100-110 \%$ $\mathrm{O}_{2}$. However, in a $20 \times 5 \mathrm{~km}^{2}$ area along the coast (Fig. 1) immediately above the primary pycnocline in the lower part of the temperature minimum, the oxygen saturation was below $30 \% \quad \mathrm{O}_{2}$. The low values were found at depths of 14 to $15.5 \mathrm{~m}$. Near the coast at Stn 3 the oxygen concentration decreased within the pycnocline. Here, a distinct subsurface oxygen saturation minimum between 2 and $5 \% \quad \mathrm{O}_{2}$ was observed, covering a depth range less than $1 \mathrm{~m}$. This coincided with the location where the fishermen traditionally had set their gill nets (fisherman S. Jørgensen pers. comm.) and where dead demersal fish were found during the first week of April. The oxygen minimum extended from this location to areas further off the coast, with gradually increasing minimum saturation 
values. Northwards $5 \mathrm{~km}$, at Stn 4 , a minimum saturation of $37 \% \mathrm{O}_{2}$ was observed at $15.5 \mathrm{~m}$ depth. At Stn 5 , about $10 \mathrm{~km}$ east-northeast from Stn 3, the minimum layer was found at $14 \mathrm{~m}$ depth with $64 \% \quad \mathrm{O}_{2}$, with $81 \% \mathrm{O}_{2}$ saturation measured below the depth 16 $\mathrm{m}$ down to the bottom $(24 \mathrm{~m})$. Further northwest and northeast, at Stns 6 and 7 , weak oxygen minimum values of 71 and $75 \% \mathrm{O}_{2}$ saturation were found at a depth of 23 to $15 \mathrm{~m}$. At these stations, oxygen saturation in the deep Kattegat water was 76 and $79 \% \quad \mathrm{O}_{2}$, respectively.

Between 8 and 9 April, the position of the primary pycnocline changed. It moved about $1 \mathrm{~m}$ downwards during a storm, and thus the intersection between the primary pycnocline and the bottom was to be found $1 \mathrm{~km}$ further off the coast. With this pycnocline movement the oxygen minimum stratum moved as well, and no oxygen depletion was found at $\operatorname{Stn} 3$ at $15.5 \mathrm{~m}$ depth. Low oxygen values $\left(32 \% \mathrm{O}_{2}\right)$ could again be recorded at the inner stations at 14 to $15.5 \mathrm{~m}$ depth, and by 26 April, the oxygen saturation on the location had decreased to $12 \%$ $\mathrm{O}_{2}$ at the depth of the pycnocline (Fig. 5c).

At the beginning of May, the oxygen saturation in the bottom water was $>56 \% \mathrm{O}_{2}$, and only moderate oxygen minimum values of $42 \% \mathrm{O}_{2}$ saturation were found in the primary pycnocline at $16 \mathrm{~m}$ depth. In midMay, the oxygen minimum in the pycnocline could no longer be detected, since the bottom water itself had an oxygen saturation of $42 \% \mathrm{O}_{2}$. At this time, low oxygen saturation characterized the bottom water of the whole southern Kattegat.

\section{Pelagic $\mathrm{O}_{2}$ respiration and net bacterial production}

Oxygen uptake rates in water samples from the oxygen minimum layer are shown in Table 3 . Here, the

Table 3. Oxygen concentration $(\mu \mathrm{M})$, plankton $\mathrm{O}_{2}$ respiration ( $\mu \mathrm{M} \mathrm{O}_{2} \mathrm{~d}^{-1}$ ), oxygen turnover time (d), and net bacterial pro-

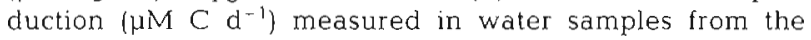
pycnocline at Stns 3 and 4 during spring. (nm: not measured)

\begin{tabular}{|lrrcc|}
\hline & $\begin{array}{c}\text { Oxygen } \\
\text { conc. } \\
\left(\mu \mathrm{M} \mathrm{O}_{2}\right)\end{array}$ & $\begin{array}{c}\text { Plankton } \\
\text { resp. } \\
\left(\mu \mathrm{M} \mathrm{O}_{2} \mathrm{~d}^{-1}\right)\end{array}$ & $\begin{array}{c}\text { Oxygen } \\
\text { turnover } \\
(\mathrm{d})\end{array}$ & $\begin{array}{c}\text { Net bact. } \\
\text { prod. } \\
\left(\mu \mathrm{M} \mathrm{C} \mathrm{d}^{-1}\right)\end{array}$ \\
\hline $\mathrm{Stn} 3$ & & & & \\
$8 \mathrm{Apr}$ & $6 \pm 3$ & $\mathrm{~nm}$ & - & $\mathrm{nm}$ \\
$14 \mathrm{Apr}$ & $98.6 \pm 0.7$ & $7.1 \pm 1.4$ & 14 & $3.6 \pm 0.2$ \\
$26 \mathrm{Apr}$ & $87.4 \pm 0.9$ & $16.0 \pm 1.9$ & 5 & $1.6 \pm 0.2$ \\
$10 \mathrm{May}$ & $150.4 \pm 0.5$ & $2.5 \pm 1.0$ & 60 & $1.1 \pm 0.2$ \\
$\mathrm{Stn} 4$ & & & & \\
$8 \mathrm{Apr}$ & $120.2 \pm 0.5$ & $14.2 \pm 1.2$ & 8 & $2.5 \pm 1.0$ \\
$14 \mathrm{Apr}$ & $180.3 \pm 0.4$ & $5.6 \pm 1.4$ & 32 & $3.1 \pm 0.2$ \\
\hline
\end{tabular}

oxygen turnover times were between 5 and $60 \mathrm{~d}$ with a minimum on 8 and 26 April. The oxygen uptake rates measured in the oxygen minimum layer were the highest recorded in the water column during this study, but considerable values were also measured in the upper layer on 8 April $\left(9.2 \mu \mathrm{M} \mathrm{O}_{2} \mathrm{~d}^{-1}\right)$. Net bacterial production in mid-April at the pycnocline was between 1.1 and $3.6 \mu \mathrm{M} \mathrm{C} \mathrm{d}{ }^{-1}$ (Table 3) Assuming a bacterial growth efficiency of $50 \%$ and a respiratory quotient (RQ) of 0.9 , a calculated bacterial $\mathrm{O}_{2}$ uptake represents 46 and $40 \%$ of the measured total pycnocline plankton respiration on 14 April and 10 May, respectively. This was not the case on 8 and 26 April, when the bacteria could only account for approximately 16 and $9 \%$ of the measured oxygen uptake.

\section{DISCUSSION}

\section{Hydrography}

The windy and cold period from the end of February until mid-March provided the energy for mixing the water column down to a depth of $13 \mathrm{~m}$ in the Kattegat and resulted in the observed cold homogeneous upper layer as seen at Stn 7 on 7 March (Fig. 3). From midMarch until the first week of April, an outflow from the Baltic Proper caused the more saline and colder water in the southern Kattegat to be covered by less saline water. Hence, the outflowing water from the Baltic Proper reduced the mixed-layer depth from 10 to $15 \mathrm{~m}$ to only a few metres. The former surface layer was maintained as an intermediate layer at the depth range 5 to $15 \mathrm{~m}$ until mid-May. The persistence of a temperature minimum in this intermediate layer indicated that the outflow provided a sufficient buoyancy input to maintain stratification within the upper $15 \mathrm{~m}$ in spite of wind mixing. Further, the persistence of the temperature minimum layer indicated that the stratification prevented wind entrainment from the bottom layer. Thus, vertical transport of dense water from below the primary pycnocline to the surface layer was small.

Simultaneous measurements showed that the salinity and temperature in the upper part of the water column in the Great Belt were similar to those found in the western part of the southern Kattegat (County of Funen unpubl. data). These findings indicated that the upper layer here primarily consisted of Great Belt water. Recent investigations in the area from the Great Belt along the northern coast of Zealand to the Sound indicate that stratification above the primary pycnocline usually is found during (or after) periods of outflow from the Baltic Proper (Bo Pedersen 1993, Rasmussen 1995). This outflow is often trapping former surface water as an intermediate layer. 


\section{Subsurface phytoplankton maxima}

Although Richardson \& Christoffersen (1991) found that the phytoplankton associated with the pycnocline in the southern Kattegat are photosynthetically active, the irradiance received by the phytoplankton just above the primary pycnocline was well below $1 \%$ of the surface value. Furthermore, several phytoplankton species did not look healthy. Thus, it seems likely that photosynthesis was small and that the observed chlorophyll a maximum was produced during the previous weeks as a result of the spring bloom. Before the spring bloom nitrate concentrations of 11 to $13 \mu \mathrm{M}$ $\mathrm{NO}_{3} \mathrm{~N} \mathrm{l}^{-1}$ were observed throughout the water column on 9 March. On 6 April the concentrations of nutrients down to the $10 \mathrm{~m}$ sampling depth had decreased to 0 (Engstrøm \& Fyrberg 1988).

\section{Surface layer oxygen supersaturation}

The supersaturation of $152 \% \quad \mathrm{O}_{2}$ found during the present investigation in the Kattegat represents a high value compared with old oxygen data sets where the maximum oxygen saturation observed was $122 \% \mathrm{O}_{2}$ (Jacobsen 1908). Evaluation of monitoring data from spring 1988 showed oxygen saturation values as high as $150 \% \mathrm{O}_{2}$ in the Great Belt surface water (County of Funen unpubl. data), $136 \% \mathrm{O}_{2}$ in Aarhus Bight (County of Aarhus unpubl. data) and $120 \% \quad \mathrm{O}_{2}$ in Northwest Kattegat (County of Northern Jutland unpubl. data). On board the Swedish RV 'Argos', 134\% $\mathrm{O}_{2}$ saturation was measured in southern Kattegat surface water (Engstrøm \& Fyrberg 1988). Thus, it seems that the spring bloom in the surface layer in late March and in the beginning of April was able to produce oxygen at a higher rate than the loss to the atmosphere. The magnitude of the oxygen consumption rates found in the water column (5 to $1.0 \mu \mathrm{M} \mathrm{O}_{2} \mathrm{~d}^{-1}$ ) could only lower the degree of supersaturation in the surface layer by 1 to $2 \% \mathrm{O}_{2} \mathrm{~d}^{-1}$. Oxygen supersaturation above $120 \% \mathrm{O}_{2}$ is seldom reported from marine areas, but Hoppema (1991) found oxygen saturation values up to $148 \% \mathrm{O}_{2}$ in the surface layer at a $19 \mathrm{~m}$ deep tidal channel in the western Wadden Sea in May 1989. The reason for the supersaturation found here was also stated to be the result of high photosynthetic activity.

\section{Oxygen supersaturation of the intermediate water layer}

The occurrence of the supersaturation in the intermediate layer might be due to photosynthetic activity from the spring bloom, taking place in the previous days and weeks. It seems that the spring bloom resulted in high phytoplankton concentrations and supersaturation above the primary pycnocline in the homogeneous cold surface water (end of March). At the beginning of April, outflow from the Baltic Proper gave rise to a stratification above the pycnocline, and the former surface water was found as the cold nutrient-poor intermediate layer with a high phytoplankton concentration and excess of oxygen. The bottom part of this cold intermediate layer was located in a lightlimited environment.

\section{A fish mortality hypothesis}

During 2 periods in April, the pycnocline was found at $15 \mathrm{~m}$ depth, and the sediment was covered by the oxygen minimum layer of 1 to $2 \mathrm{~km}$ width along the coast. As the oxygen minimum layer moved upwards, due to pycnocline movements, it approximately covered the lower $1 \mathrm{~m}$ of the fishing nets in the area causing suffocation of the trapped fish. Local fishermen reported an extraordinarily high catch of small sole Solea solea, dab Limanda limanda and plaice Pleuronectes platessa in the days prior to the kill, which indicates that changes in the position of the pycnocline caused an escape response in the fish to avoid the oxygen minimum layer. In April 1988, an incident of bottom fauna mortality at $14 \mathrm{~m}$ depth from the northern coast of the island of Anholt in the Kattegat was observed (O. Norden pers. comm.), indicating that this is a more widespread phenomenon in Danish waters.

Fish kill events from shallow water areas have been reported from the region before, for instance, in the late summer 1981 near Flensburg Fjord in the western Baltic, where fish died in gill nets at 4 to $6 \mathrm{~m}$ depth, most likely due to upwelling of oxygen-free bottom water caused by strong winds from the coast (Weigelt \& Rumohr 1986).

\section{Oxygen minimum layers and plankton oxygen budget}

The distinct oxygen minimum between the upper and the lower layer seems to be caused by a high oxygen consumption by planktonic organisms in the isolated water layer. To illustrate the potential role of the different organisms, a plankton $\mathrm{O}_{2}$ respiration budget for the dominating planktonic organisms in the pycnocline during the spring was constructed (Table 4). Although the budget was based on a number of assumptions, it misses only between 9 and $28 \%$ of the total oxygen uptake measured in the pycnocline water. The respiration ratio of phytoplankton versus bacteria changes from 19:50 on 14 April, to 60:12 on 26 April, while on 10 May it was $41: 51$. The oxygen consumption 
was not dominated by the bacteria alone. The phytoplankton played an important role as well. In April, the microzooplankton and the flagellates accounted for approximately $30 \%$ of the consumption, which is a rather high amount compared to the results by SandJensen et al. (1990). A similar pattern was observed during summer in the western Long Island Sound (USA), with a maximum oxygen consumption in the pycnocline and reduced values below, causing an oxygen minimum layer over a depth range of 1.8 to $4.5 \mathrm{~m}$ at temperatures of $17^{\circ} \mathrm{C}$ (Welsh \& Eller 1991). Even though the water temperature was higher, the order of magnitude for the oxygen consumption rate (10 to $\left.20 \mu \mathrm{M} \mathrm{O}_{2} \mathrm{~d}^{-1}\right)$ in the water column was the same as was found in the Kattegat.

The maximum plankton respiration in the southern Kattegat pycnocline $\left(16 \mu \mathrm{M} \mathrm{O}_{2} \mathrm{~d}^{-1}\right)$ was 4 times higher that mean values reported from the whole bottom water in the eastern Kattegat in March 1988 (Rydberg et al. 1990). The oxygen uptake rates were in the same range as found by Kemp et al. (1992) in Chesapeake Bay surface and bottom water in spring 1986 to 1987 (3.1 to $21.9 \mu \mathrm{M} \mathrm{O}_{2} \mathrm{~d}^{-1}$ ). The bacterial net production in the pycnocline was twice as high as maximum values found in subsurface chlorophyll a maximum at the Dogger Bank (North Sea) by Nielsen et al. (1993). The occurrence of an oxygen minimum between the temperature minimum and the warmer bottom layer suggests a possible effect of the increase in temperature on the oxygen consumption as reported by Shiah \& Ducklow (1994).

The development of an oxygen-depleted layer at the primary pycnocline can be explained by: (1) reduced depth penetration of light due to large phytoplankton concentrations near the surface, thus reducing the photosynthetic activity and oxygen production below; (2) a small vertical oxygen exchange due to the stable upper layer, which was created during the previous weeks as a result of low wind mixing and of outflow from the Baltic Proper. The development of the oxygen minimum layer was closely connected to the period of stratification of the upper $15 \mathrm{~m}$, which isolated the phytoplankton from the light and allowed for the development and growth of a heterotrophic community.

Off the coast, the minimum oxygen saturation did not reach values as low as in the area where the pycnocline intersected the bottom. It seerms likely that the lowest oxygen saturation found at the intersection is caused by the combined effect of the oxygen consumption in the water column and in the sediment.
Off the coast, only plankton community respiration can reduce the oxygen concentration at the pycnocline. Sediment oxygen uptake was not measured in this study, but in April 1989 the sediment oxygen uptake rate was determined to be $12 \mathrm{mmol} \mathrm{O} \mathrm{m}^{-2} \mathrm{~d}^{-1}$ in sediment cores from Stn 4 (Kruse unpubl. data). Similar rates were found at $15 \mathrm{~m}$ depth in Aarhus Bay sediments (Rasmussen \& Jørgensen 1992). Assuming that the sediment oxygen uptake rate had this order of magnitude in April 1988 and including the pelagic respiration, the total loss on 26 April would be 28 mmol $\mathrm{O}_{2} \mathrm{~m}^{-3} \mathrm{~d}^{-1}$ resulting in an oxygen turnover of $3.1 \mathrm{~d}$ in the $1 \mathrm{~m}$ subsurface minimum layer above the sediment.

In earlier investigations (1904 to 1907; Jacobsen 1908) oxygen minimum layers were found; however, the values were not lower than $65 \% \mathrm{O}_{2}$ at the pycnocline and with a saturation in the bottom water of about 80 to $90 \% \mathrm{O}_{2}$ (minimum value of $54 \% \mathrm{O}_{2}$ in November). New extensive oxygen data sets (1974 to 1979, Extebjerg et al. 1981) show reduced oxygen saturation in the bottom water (less than $20 \% \mathrm{O}_{2}$ ) but not oxygen minimum layers. It seems that there has been a decrease in the oxygen saturation in both the bottom water and in the oxygen minimum layer since the beginning of this century, even though the data do not allow for conclusive trends with respect to the oxygen minimum layer. However, the fact that the 3 


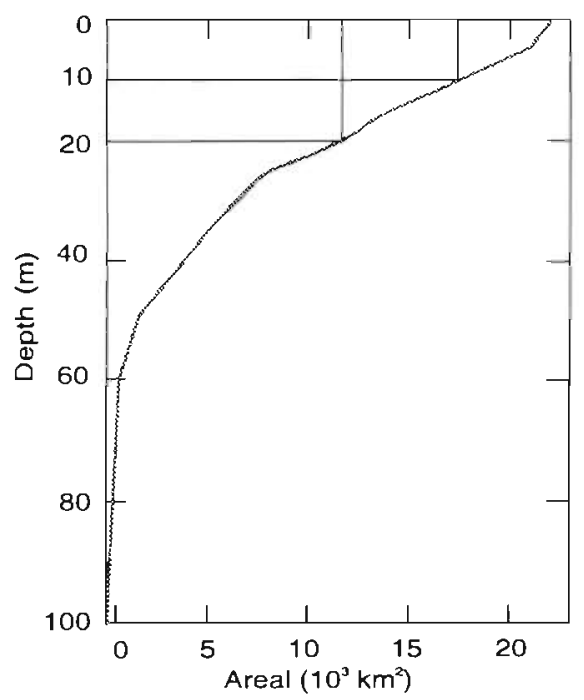

Fig. 7. Depth distribution of bottom area in the Kattegat. The pycnocine-influenced sediment zone defined as the depths between 10 and $20 \mathrm{~m}$ is indicated. This zone represents $7000 \mathrm{~km}^{2}$ or $1 / 4$ of the sediments in the Kattegat

incidents of fish kills in the area all are fairly recent events $(1984,1986$ and 1988) supports the assumption that the minimum oxygen values in the pycnocline also have decreased.

\section{CONCLUSION}

Outflow of low-salinity surface water from Baltic Proper in March created a near-surface stratification in the southern Kattegat which maintained the phytoplankton and other microorganisms at a depth of low light intensity. Respiration from these organisms caused the development of an oxygen minimum layer just above the primary pycnocline. Above, high oxygen concentrations were found as a result of the spring bloom. Density differences prevented wind mixing from reaching the developing oxygen minimum layer. Near the coast, where the minimum layer was influenced by sediment respiration, the oxygen concentrations were even lower. The fish kill was most probably caused by the oxygen minimum water layer covering fish trapped within the fishing nets.

The subsurface phytoplankton maxima often coincide with the area where the primary pycnocline intersects the bottom. This zone might be considered as very biologically active (Jensen et al. 1994), which might explain the intensive fishery activity (and fish kills) here. The area of the bottom influenced by the pycnocline in the Kattegat is considerable (Fig. 7), and further studies of the role of this zone are needed.
Acknowledgements. We thank Finn Andersen, Ragnhild $M$. Jensen, Dorete W. Jensen, Steen Pedersen and Kurt Jensen for technical assistance. We are grateful to the Swedish Meteorological and Hydrographic Institute, and to the Counties of Funen, Frederiksborg, Aarhus, and Northern Jutland in Denmark for data and information. We are also grateful to Henning Hundahl and Niels K. Hrjerslev at the Niels Bohr Institute, University of Copenhagen, for lending us fluorometer equipment. We thank fisherman Svend Jørgensen and Hanne Kaas for skilful assistance and valuable discussions. The manuscript has benefitted from criticism by Amanda Cohen, Bente Lomstein, Torkel Gissel Nielsen, Flemming Møhlenberg, Kirsten Djørup and Dan Conley. Financial support was provided by the Danish Research Academy and by the National Environmental Protection Agency (Program; HAV90 no. 2.36 )

\section{LITERATURE CITED}

Ertebjerg G, Jacobsen TS, Gargas E, Buch E (1981) The Belt Project; evaluation of the physical, chemical and biological measurements. NEPA, Copenhagen, DenmarkAndersson L, Rydberg L (1988) Trends in nutrient and oxygen conditions within the Kattegat: effects of local nutrient supply. Estuar coast Shelf Sci 26:559-579

Bjørnsen PK (1986) Automatic determinations of bacterioplankton biomass by means of image analysis. Appl environ Microbiol 51:1099-1104

Bjornsen PK, Nielsen TG (1991) Decimeter scale heterogeneity in the plankton during pycnocline bloom of Gyrodinium aureolum. Mar Ecol Prog Ser 73:263-267

Bo Pedersen F (1993) Fronts in the Kattegat: the hydrodynamic regulating factor for biology. Estuaries 16:104-112

Boesch DF, Rabalais NN (1991) Effects of hypoxia on continental shelf benthos: comparisons between the New York Bight and the Northern Gulf of Mexico. In: Tyson RV, Pearson TH (eds) Modern and ancient continental shelf anoxia. The Geological Society Spec Publ no. 58, London, p $27-34$

Dietrich G (1954) Oberflächensströmungen im Kattegat, im Sund und in der Belt See. Dt Hydrogr Z 4:129-151

Edler L (1979) Recommendations on methods for marine biological studies in the Balitic Sea - phytoplankton and chlorophyll. The Baltic Marine Biologists, Publ 5. Institute of Hydrographic Research, Lysekil, Sweden

Engström S, Fyrberg L (1988) Rapport från oceanografiska expedition med miljökvalitets-övervakning i Kattegat och Skagerrak, April 1988. SMHI, Göteborg (in Swedish)

Fenchel T (1987) Ecology of Protozoa - the biology of freeliving phagotrophic protists. Springer-Verlag, Berlin

Frederiksborg Amt (1990) Miljoovervägning af kystvandene. Afrapportering 1980-90. Hillerød, Danmark (in Danish)

Graf G (1987) Benthic response to the annual sedimentation patterns. In: Rumohr H, Walger E, Zeitzschel B (eds) Seawater - sediment interactions in coastal waters. An interdisciplinary approach. Lecture notes on coastal and estuarine studies, Vol 13. Springer-Verlag, Berlin, p 84-92

Hobbie JE, Daley RJ, Japser $S$ (1977). Use of Nucleopore filters for counting bacteria by fluorescence microscopy. Appl environ Microbiol 33:1225-1228

Hoppema JMJ (1991) The oxygen budget of the western Wadden Sea, The Netherlands. Estuar Coast Shelf Sci 32: 483-502

Hundahl H, Holck $J$ (1980) A new in situ fluorometer for detection of Rhodamine B and Chlorophyll. Rep No 42, Inst Physical Oceanogr, Univ Copenhagen, p 145-154 
Jacobsen JP (1908) Der Sauerstoffgehalt des Meereswassers in den daenischen Gewaessern innerhalb Skagens. Meddr Komm Havunders (Ser Hydrografi) 1(12):1-23

Jacobsen TS (1980) Sea water exchange of the Baltic. The National Agency of Environmental Protection, Charlottenlund, Denmark

Jensen JN, Josefson A, Dinesen G (1994) Effekter af springlagsopblomstringer pá benthos. Havforskning fra Miljostyrelsen, rapp no 34. Miljoministenet, Copenhagen, Denmark (in Danish with English summary)

Jorgensen BB (1980) Seasonal oxygen depletion in the bottom waters of a Danish fjord and its effect on the benthic community. Oikos 34:68-76

Jespersen AM, Christoffersen K (1987) Measurements of chlorophyll a from phytoplankton using ethanol as extraction solvent. Arch Hydrobiol 109:445-454

Kanneworff E, Christensen H (1986) Benthic community respiration in relation to sedimentation of phytoplankton in the Øresund. Ophelia 26:269-284

Kemp WM, Sampou PA, Garber J, Tuttle J, Boynton WR (1992) Seasonal depletion of oxygen from bottom waters of Chesapeake Bay: roles of benthic and planktonic respiration and physical exchange processes. Mar Ecol Prog Ser 85:137-152

Kronvang B, Ertebjerg G, Grant R, Kristensen P, Hovmand M, Kirkegaard J (1993) The nation-wide Danish monitoring programme - state of the aquatic environment. Ministry of the Environment, Denmark

Kruse B (1993) Measurements of plankton $\mathrm{O}_{2}$ respiration in gastight plastic bags. Mar Ecol Prog Ser 94:155-163

Kuparinen J (1987) Production and respiration of overall plankton and ultraplankton communities at the entrance to the Gulf of Finland in the Baltic Sea. Mar Biol 93:591-607

Malone I (1991) River flow, phytoplankton production and oxygen depletion in Chesapeake Bay. In: Tyson RV, Pearson TH (eds) Modern and ancient continental shelf anoxia. The Geological Society Spec Publ no 58, London, p 83-93

Nielsen GA, Bresta AM (1984) Guidelines for the measurement of phytoplankton primary production. The Baitic Marine Biologists, Publ No 1, 2nd edn, Charlottenlund

Nielsen TG, Løkkegaard B, Richardson K, Bo Pedersen F, Hansen L (1993) Structure of plankton communities in the Dogger Bank (North Sea) during a stratified situation. Mar Ecol Prog Ser 95:115-131

Pedersen FBo, Møller JS (1981) Diversion of the River Neva, how will it influence the Baltic Sea, the Belts and Kattegat. Nord Hydrol 12:1-20

Olesen $M$ (1992) Sedimentation af autochont materiale i

This article was submitted to the editor lagdelte havområder. Marine Biological Laboratory, Univ of Copenhagen, Helsingor

Rasmussen B (1994) Blandingsmekanismer i kystnæere farvande - Havforskning fra Miljostyrelsen, rapp no 32 Miljøministeriet, Copenhagen, Denmark (in Danish with English summary)

Rasmussen B (1995) Stratification and wind mixing in the southern Kattegat. Ophelia 42:319-334

Rasmussen H, Jørgensen BB (1992) Microelectrode studies of seasonal oxygen uptake in a coastal sediment: role of molecular diffusion. Mar Ecol Prog Ser 81:299-303

Richardson K, Christoffersen A (1991) Seasonal distribution and production of phytoplankton in the southern Kattegat Mar Ecol Prog Ser 78:217-227

Rosenberg R (1985) Eutrophication - the future marine coastal nuisance? Mar Pollut Bull 16:227-231

Rumohr Hv (1986) Historische Indizien für EutrophierungsErscheinungen (1985-1939) in Kieler Bucht (westliche Ostsee). Meeresforsch 31, H2:115-123

Rydberg L, Edler L, Floderus S, Graneli W (1990) Interaction between supply of nutrients, primary production, sedimentation and oxygen consumption in SE Kattegat. AMBIO 19:134-141

Sand-Jensen K, Jensen LM, Marcher S, Hansen M (1990) Pelagic metabolism in eutrophic coastal waters during a late summer period. Mar Ecol Prog Ser 65:63-72

Shiah FK, Ducklow HW (1994) Temperature and substrate regulation of bacterial abundance, production and specific growth rate in Chesapeake Bay, USA. Mar Ecol Prog Ser 103:297-308

Simpson JH, Brown J, Matthews J, Allen G (1990) Tidal straining, density currents, and stirring in the control of estuarine stratification. Estuaries 13:125-132

Stanley DW, Nixon SW (1992) Stratification and bottom-water hypoxia in the Pamlico River estuary. Estuaries 15: $270-281$

Weigelt M, Rumohr H (1986) Effects of wide-range oxygen depletion on benthic fauna and demersal fish in Kiel Bay 1981-1983. Meeresforsch 31, H2:124-136

Welsh BL, Eller FC (1991) Mechanisms controlling summertime oxygen depletion in western Long Island Sound. Estuaries 14:265-278

Westerhagen $H$ v, Hickel W, Bauerfeind E, Niermann U, Kröncke I (1986) Sources and effects of oxygen deficiencies in the South-Eastern North Sea. Ophelia 26:457-473

Williams PJ leB, Jenkinson NW (1982) A transportable microprocessor-controlled precise Winkler titration suitable for field station and shipboard use. Limnol Oceanogr 27 $576-584$

Manuscript first received: March 3, 1994 Revised version accepted: March 23, 1995 